PaUl Trawick

Department of Anthropology

University of Kentucky

Lexington, KY 40506-0024

\title{
The Moral Economy of Water: Equity and Antiquity in the Andean Commons
}

\begin{abstract}
This article focuses on irrigation and water use in a community in the Peruvian Andes, one of numerous villages in the region where these activities are carried out in an unusual way. The practices and principles that make up this tradition, defining the rights and duties of community members in making use of the resource most vital for life, are identified and evaluated based on comparative ethnographic research. It is argued that they provide a highly effective way of managing a scarce and fluctuating resource that is held in common, an older Andean tradition that may have been adopted by the Incas and endorsed as an official policy - all of which might help to account for its wide distribution in the region today. In this particular case, the principles help to create an extraordinary kind of community, a transparent and equitable one in which a basic material symmetry or proportionality is expressed at many levels. This symmetry is closely related to other basic commonalities among community members, but of particular interest are its effects on social solidarity and cooperation and its association with a strong sense of ethnic identity. The implications of this tradition for solving contemporary problems in water management are also briefly discussed. [sociocultural anthropology, irrigation, Andes, common-property]
\end{abstract}

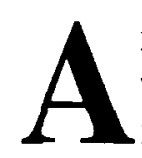
nthropologists have long sought to understand the ways in which irrigation has shaped the development of societies in relatively arid parts of the world, beginning with Steward (1949, 1955) and Wittfogel (1955, 1957). This interest reflects a broader fascination with the nature/ culture relationship-one of the great enduring themes, now understood to require a kind of ecological research that is historical and quite broad in scope (Biersack 1999; Kottak 1999), but still focused in some basic way on material relations. Yet the ethnographic study of irrigation began rather late, and, until recently, it did not appear to have taken us very far. The main thing learned during the early years was that hydraulic systems come in many shapes and sizes in various kinds of environments, so that, unless we narrow the field of inquiry and make some initial assumptions, few interesting generalizations can be made about them. The comparative study of these systems, which began in the 1960s but did not start to see significant advances until the 1980s (Hunt 1988; Kelly 1983), only reinforced this point of view.

By limiting discussion in the simplest way, geographically, it becomes possible to make a few general statements about one major region of study, the Andes of Peru: (1) a distinctive kind of watering system was constructed there in prehistoric times-small-scale, vertically oriented canal systems, typically fed by alpine springs; (2) this was the only kind that could be built in most areas, due to limitations imposed by the topography and climate (Trawick 1994a:35-36); and (3) these small systems have, throughout history, formed the basis of a certain type of society, a village society or "micro-society" (Schaedel 1971). The canal systems, generally encompassing less than 1,000 hectares of land (Hunt 1988), are often highly self-sufficient in terms of water supply, giving these societies the potential for a basic kind of autonomy. In this respect they are distinct from those of the Peruvian coast, and other parts of the globe, where the canal systems tap big water sources - rivers - where they are large in scale, usually encompassing several communities, and where they tend to be tied to one another through upstream-downstream arrangements for sharing water.

Nevertheless, it has always been difficult, in the study of small-scale systems, to make any major generalizations about them, even within the Andean region alone. And this has been true despite significant advances in ethnographic research-a body of excellent descriptive and analytical work. Fortunately, the picture is no longer so confusing, as I will try to show here. Recent research, solne of which I conducted myself in Peru, has made it possible to see that there exists a distinctive arrangement for managing water at the local community level, a highly transparent system that once prevailed widely and is still found in some villages in the Andes today. This tradition forms the "core" of these societies in an ecological and economic sense, as well as a moral one, being a set of rules and principles for sharing scarce water that has been retained by the local 
people over a very long period of time. Having thus been continually reaffirmed and ratified, it can be considered a form of self-organization or self-regulation by the community.

Constructed in this way around the long-term management of common property, the tradition is, as I have shown elsewhere (Trawick 1994b, 2001, in press), highly effective in dealing with a scarce and fluctuating resource, indeed superior to several other kinds of systems found in the region today. Where water is generally adequate or abundant, other rules and principles may perhaps work as well, but that is rarely the case in the Andes and many other parts of the world. Here I will describe the tradition in detail but focus mainly on its ethical dimension-on equity in water sharing as the moral foundation of village life-and show how, in at least one of the communities where it still exists, the tradition helps to foster an unusual kind of cooperation and solidarity among members. Second, I will deal with the question of its origins. There is good evidence that this kind of system and community prevailed throughout arid parts of the Andes during late prehistoric times, at least in situations where the resource was scarce, and that the Incas adopted and endorsed it as an official policy. Given the serious problems that afflict water management in the region today, this latter point is of more than historical interest.

\section{The Study of Andean Irrigation}

When I began my fieldwork in Peru, during the mid1980 s, a great amount of ethnographic work had been done, and even more community studies were underway, but these had revealed only a few commonalities and led to a rather confusing picture. The first detailed studies of Andean watering systems - all following on the early work of Mitchell (e.g., 1976, 1980)-had revealed striking variation in nearly every aspect but their size, from basic organization to modes of distribution to utilization techniques. One feature had been recognized immediately: due to the scarcity of the resource and the small size of most water sources, these are typically turno systems, in which households take turns in using a given source rather than doing so at the same time, making irrigation a serial rather than a parallel process. But few other generalizations could be made-other than that, as many ethnographers had noted, the resource was typically scarce, much of it was wasted, and conflict over it seemed to be the rule. Mitchell (1976) had noted the prevalence of a kind of dual system in which two adjacent canal networks, each fed by their own mountain springs, underlay a dual social organization that was hydrographically based, at least in part. But that kind of system and community, although common, was far from universal. All the diversity made it appear doubtful, as of the early 1990s, that any widespread tradition of water management had ever existed, much less an egalitarian one, as many people had previously thought. ${ }^{1}$
Because it was difficult to see any clear pattern in the ethnographic record, there had emerged by that time among Andean ethnographers a tacit consensus-slightly less firm today (Guillet 1994; Treacy 1994a, 1994b)-that a significant amount of regional and local variation must have existed in the distant past, just as in the present, in terms of the principles governing organization and use of the resource. Finding this doubtful, I tried to show, during nearly four years of ethnographic fieldwork in the southern highlands, that the villages and traditions documented in the literature are the diverse outcomes of processes of change that, though quite complex, were highly similar over much of that vast region. I found that the changes that have been most pivotal in irrigation occurred in a definite historical sequence, that they were largely exogenous in origin, and that they set in motion a process of technological, ecological, and social decline-a "tragedy of the commons" (Hardin 1968) — whose symptoms have been widely documented, but which led to diverse outcomes (Trawick 1994a, 1994b, in press). What I did not expect to find, however, was, in a sense, the point from which all of these changes began, the kind of community to be described below.

My reading of irrigation history was based on a comparative ethnography of three communities in one highland province, the first of its kind to be done. The villages are located in the Cotahuasi Valley of the Department of Arequipa, in the southern part of the country, one of the more remote provinces on the arid western Andean slope. They were chosen for two reasons. They have in common the small-scale type of canal system found virtually everywhere throughout the sierra, but they differ systematically and cover a wide range of the variation found in the region today among communities that are unified and have a central authority (Hunt 1988), which are the vast majority. All three are composed of large and small landowners-mayoristas and minoristas, respectively-and all grow basically the same array of crops, including pasture for animals (alfalfa), but they vary in their ethnic composition and degree of autonomy. They also differ according to altitude, proximity to the road and to adjacent provinces, and other factors, and form a kind of rural-urban continuum, though all within a very rural context.

The first village, Huaynacotas (population 1,073), is a remote village of peasants whose primary language is Quechua. It is rather closed, corporate, and located at high altitude (3,300 meters). During the colonial and modem periods it has remained relatively independent of hacienda influence-never having allowed Spanish landlords to settle in its territory and acquire land there, unlike most other local communities-and unaffected by the State's intervention into local water affairs. The second village, Pampamarca, is a predominantly Quechua-speaking village (population 942), remote and at high altitude (3,500 meters), that has long been controlled by a small minority of 
resident landlords, but where the impact of state institutions has likewise not been felt in irrigation. The third, Cotahuasi, is a criollo and mestizo district (the provincial capital) that has long been the center of local commerce and state administration and that remained thoroughly dominated, up until Peru's agrarian reform in 1969, by a group of merchant-landlords and their families, people of direct Spanish descent.

This elite population (culturally Spanish, often describing themselves as "gente español") is notorious in the Arequipa region for having maintained its dominance over most valley communities until the end of the twentieth century, a preeminent position based in part on the strict practice of ethnic and class endogamy (Montoya 1980:144). In Cotahuasi district, three outlying villages-high-altitude ones that were formerly indigenous-have long shared their irrigation system with the dominant town (Cotahuasi, population 1,340) and provided the local estates with both water and labor. It is in these communities, the only ones in my study that are accessible by road, that the State's presence has been felt in irrigation. As in many provincial capitals, the resource was for a long time administered by a Technician according to the General Water Law of $1969 .{ }^{2}$ Only Huaynacotas will be discussed here, but the other communities, along with others in the valley with which I am familiar, and still others in adjacent parts of southern Peru, will provide a context for some comparative observations.

\section{On Irrigation History}

My interpretation of what I learned and observed in the field was refracted through a certain lens, a set of assumptions I thought I could safely make, based on what we know about the distant past and more recent periods. I assumed, based on sound evidence, that throughout the Andes the current pattern of hydraulic and landscaping practices in each community is the outcome of three gradual processes or sets of changing historical conditions. These provided a context within which changes in irrigation were likely, indeed almost certain, to take place. They were: (1) the establishment during prehistoric times of deliberate methods for managing a scarce resource among populations approximating those found in the region today (Cook 1981); (2) a massive reduction in the intensity of land and water use during the colonial period due to a sustained population collapse - one that must have created an extraordinary situation of water abundance; and, finally, (3) a gradual re-intensification in response to demographic recovery of the indigenous population during recent times (Gootenberg 1991) combined with the simultaneous growth of regional export economies in many areas.

This latter process of intensification, being based on the expansion of agricultural estates (Flores-Galindo 1977; Grieshaber 1979) and accompanying privatization of water
(Fuenzalida et al. 1982; Mitchell 1994; Trawick in press), created a situation of conflict and ultimately helped to create the water scarcity that is so prevalent today. By doing a historical and ethnographic study of three very different communities, I was able to show how two exogenous agents-local landlords (owners of the commercial estates) and the State, with its legal and administrative institutionsset this conflict in motion by imposing a new kind of political ecology in an entire region, one that produced rather diverse outcomes but did leave a few communities fairly intact.

To arrive at these conclusions, and to trace irrigation history, of course required some knowledge about the kind of hydraulic tradition that may have prevailed originally in the valley and perhaps in other parts of the Andes. In beginning the study, I had only two sources of information about this, coming from the only two chroniclers-the Inca Garcilaso de la Vega and Guaman Poma de Ayala--who had anything substantial to say about irrigation in the provinces during Inca times. Their accounts, although brief, both indicated that there was, indeed, a widespread tradition of water management, in effect an Inca water policy. The most detailed description was that of Garcilaso ([1609] 1966:248):

In districts where the quantity of water for irrigation was small, they divided it proportionately, as they did with everything they shared out, so that there would be no dispute among the Indians about obtaining it. This was only done in years of scanty rainfall when the need was greatest. The water was measured, and as it was known from experience how long it took to irrigate a fanega of land, each Indian was accordingly granted the number of hours' supply he needed for the amount of land he had, with plenty to spare. Water was taken by turns, according to the order of the plots of land, one after another. No preference was given to the rich or nobles, or to favorites or relatives of the curaca [local chief] or to the curaca himself, or to royal officials or governors. Anyone who neglected to irrigate his land at the proper time received an ignominious punishment.

In a similar vein, Guaman Poma ([1613]1978:356, 246, $848,1040,1237)$ spoke repeatedly and admiringly of the same thing, explicitly in reference to water management: an ancient tradition of fairness and justice between elites and commoners in a land where the resource was scarce, unpredictable, and a source of constant concern. These intriguing reports, although they could not be taken at face value, suggested that all the local communities had, indeed, developed out of one original tradition. Yet it seemed unlikely, given all the catastrophic changes of the colonial and modem periods, that this might still exist in some places.

\section{Huaynacotas: An Autonomous Peasant Community}

The village of Huaynacotas is one of only a few in the Cotahuasi valley that has no haciendas within its territory 
and no ethnic minority of landlords among its residents. Here, methods of sharing water and irrigating are distinctive and remain intact. Significantly, the same set of practices is found in two other local communities that managed to maintain their autonomy in this same way, and not anywhere else. ${ }^{3}$ In my opinion, we see in Huaynacotas and other villages like it an evolved modern version of a tradition that once prevailed throughout arid parts of the highlands, which is to say in most of the region. Not long into my research I realized that it is just the kind of system that the two chroniclers above were describing. The members of the community claim that this heritage is Inca, and, although I think it is probably far older than that, in a certain sense I am sure they are right.

I do not mean to suggest, however, that Huaynacotas is pristine, having escaped colonization entirely. Rather, it is not dominated by an ethnic minority and is therefore one of the few villages that have remained autonomous in the domain of water management. The village itself, as a nucleated settlement, dates back to the reducciones (population resettlements) of the sixteenth century, like most highland communities. Its people had to serve in the Spanish mita (forced labor in the mines), and in most respects they suffered the same fate as other Andean people during the colonial period. Politically speaking it is an annex community, subordinate to the district and provincial capitals; thus it has a long history of leadership by local people who were appointed by outsiders rather than elected (alcaldes). The village, a three hours' walk above the nearest road, is today a comunidad campesina, or legally recognized peasant community, a protected status that its leaders were able to gain from the national government in 1965 .

There is also a lengthy history of seasonal and, more recently, permanent migration by community members, which began shortly after World War II but only became substantial after the road reached the valley in 1960. It then increased steadily with sustained population growth. Consequently, here as elsewhere in the highlands, most households now have some members living in the city, and many families have moved there permanently, a trend that has reduced the rate of population growth (indeed has led to significant depopulation here and everywhere else in the valley) and ultimately limited pressure on the land. Economic ties with the provincial capital and with coastal valleys areas are limited, however, to occasional wage labor on the local estates by male household members and seasonal migration to plantations and mines. There is no local production of crops for the market, only occasional sales of cattle to middlemen who frequent the lower part of the valley.

Regarding the haciendas, what happened here is that the community - today composed of three ayllus, or kinship groups--long ago lost all of its low-altitude land to the estates that lie along the valley bottom. It then simply contracted its boundaries and managed to prevent further losses of land and water from that point onward. Two sepa- rate communities were established on those low-altitude lands. Note that these may originally have belonged to the two halves, or moieties, of Huaynacotas, according to the well-known saya system of dual organization, known to have been adopted by the Incas, of which more will be said below.

The hydraulic and land-use system is complex and has been described in detail elsewhere (Trawick 1994a, 2001, in press) but is depicted below (see Figure 1). Spanning elevations from 3,100 to 4,100 meters, it encompasses roughly 410 hectares, territory that is divided into named sectors and consists of two different kinds of land. Approximately 73 percent is irrigated intensively and used to produce maize and other staples, as well as some alfalfa. The other type is primarily rain-fed and, here as elsewhere in the region, was formerly used to grow potatoes and other tuber crops (Guillet 1981; Orlove and Godoy 1986). These sectors, called t'ikras, lie at high altitude and receive much more rainfall, but here some of the sectors were irrigated for planting and watered again thereafter if the need arose. All of them now lie abandoned, however, due to a recurrent drought that began in the late 1970s and has only recently begun to show signs of ending. Thus irrigation has long been confined to the maize-growing zone.

The order in which the sectors were formerly planted and watered (including the abandoned sectors) is shown in Figure 1. Note that sectors having the same number with the added designations " $a$ " and " $b$ " are watered simultaneously, using the daily outflow of a reservoir, on the one hand, and the daytime flow of the main canal above that same tank, on the other. Otherwise the two flows are usually combined to irrigate the same sector. For the maizegrowing sectors, the watering sequence is determined by microclimatic variation making some areas significantly colder than others, which extends the germination time for maize plants and increases the frequency of frosts coming at the end of the year. Consequently, those sectors have to be given a head start. This explains why the sequence does not proceed steadily from the upper sectors to the lower, as one would otherwise expect (Mitchell 1976). Field preparation and planting start the cycle, which is repeated until irrigation ceases after the rains begin. Since there are no low-altitude lands still belonging to the community, double cropping and an early planting (often called mishka) are not possible here.

\section{The Irrigation Systems}

The irrigation system is actually a dual one with two major water sources, two storage reservoirs, and two separate networks of canals, which are entirely independent. Note that most households have tiny plots of land scattered throughout both halves of the system, so that the ayllus are not territorial or corporate groups. The two networks are operated by the village members through a system of rotating 
allocated authority in which customary procedures are followed. During each irrigation cycle, two elected water distributors, called Campos (one for each half), divide the flows of the main canals in half, into two standard and roughly equivalent portions called rakis, in the act of diverting them into the secondary canals (see Montoya et al. [1979] and Treacy [1994a] on rakis). They then allow the water to flow down to the fields, where each share is used by a landowning family or household. The rules and principles governing water use are essentially identical in both canal networks, which can otherwise be considered separate systems. In describing this local tradition as singular and calling it highly efficient, note that I am referring to those customary procedures themselves, not the dual canal arrangement, whose structure is determined by hydrology and topography. As I have argued elsewhere (Trawick 1995), these local practices could be adopted, with beneficial results, in any kind of canal system, whether of one, two, three, or four sections.

The entire landscape has been terraced into level surfaces that are designed, and carefully maintained, to promote the absorption of water. ${ }^{4}$ Because of this the watering can be carried out by means of a uniform technique, one which helps to ensure that the duration of irrigation and the amount of water consumed by people in their allotments are strictly proportional to the extent of each property. Though some adjustments are made for variations in soil type, this basic symmetry is maintained by the fact that all cultivated surfaces are virtually level, and standard waterpooling features (atus) are used by everyone (see Fignre 2). Because liquid is accumulated on the surface to a uniform depth, the regulation of irrigation time and of water consumption is an inherent feature of the technology. ${ }^{5}$ No departures from this arrangement- such as the destruction of terracing and the irrigation of slopes, practices common in Pampamarca, Cotahuasi, and other places formerly dominated by haciendas-are allowed by the Water Distributors. Thus these procedures, and all the others to be described below, are not just techniques but also rules according to which water use is supposed to take place. ${ }^{6}$

Several practices ensure that all plots of land served by a given source get water from the Distributors with the same frequency, which varies with seasonal and long-term

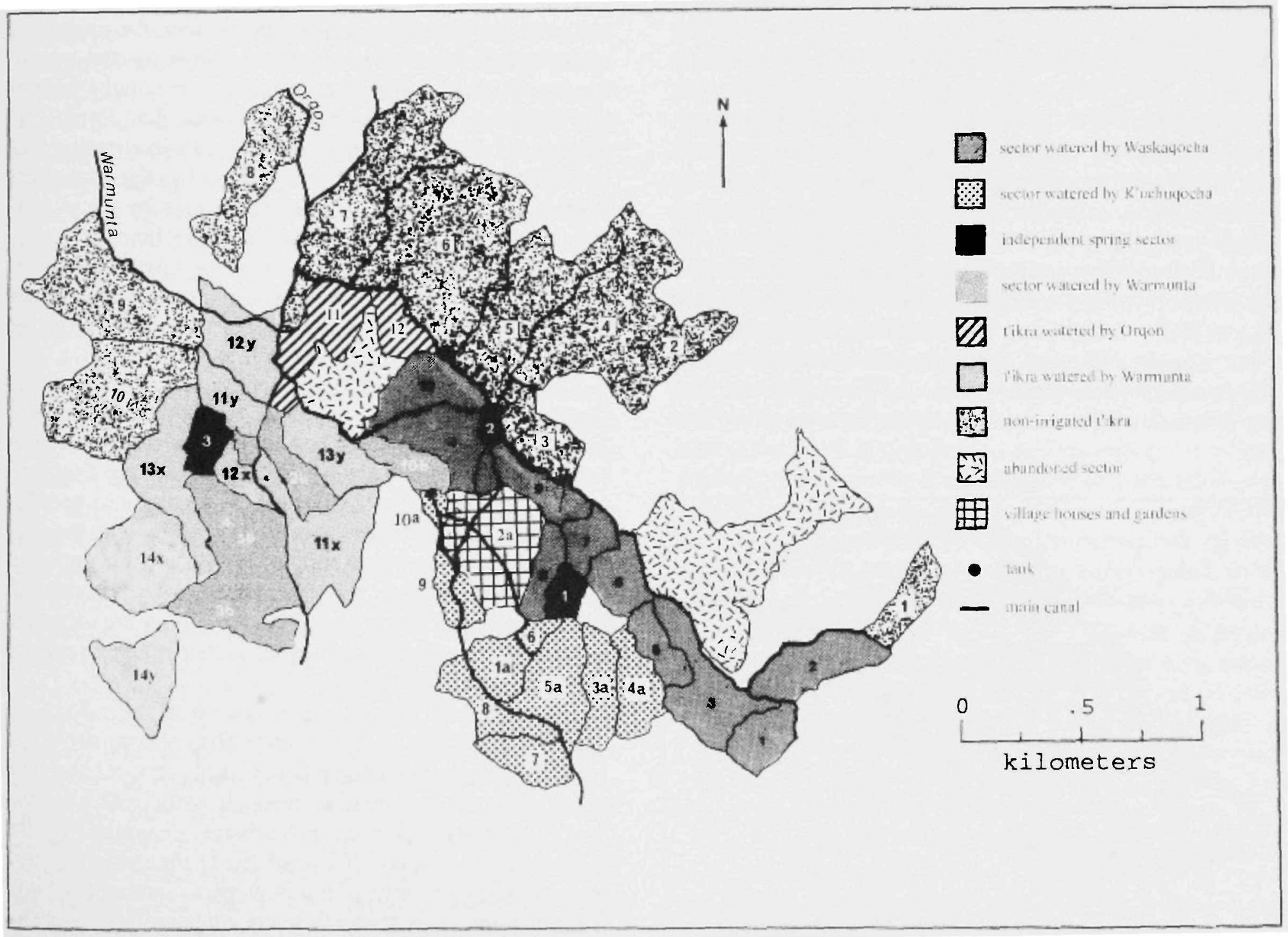

Figure 1. Irrigation and land-usc syslcm of Huaynacotas. 
Table 1. Basic principles of irrigation in Huaynacotas.

(1) Autonomy: the community has and controls its own flow of water.

(2) Uniformity

among water rights: everyone receives water with the same frequency.

in technique: everyone irrigates in the same way.

(3) Contiguity: water is distributed to fields in a fixed contiguous order based only on their location along successive canals.

(4) Proportionality (equity or fairness)

among rights: no one may use more water than the amount to which the extent of their land entitles them, nor may they legally get it more often than everyone else.

among duties: people's contributions to maintenance must be proportional to the amount of irrigated land that they have.

(5) Regularity: things are always done in the same way under conditions of scarcity; no exceptions are allowed, and any sudden expansion of irrigation is prohibited

(6) Transparency: everyone knows the rules and has the ability to confirm, with their own eyes, whether or not those rules are generally being obeyed, to detect and denounce any violations that occur.

makes possible an equally remarkable capacity for selfmanagement by the comuneros, ${ }^{10}$ or community members. Ulimately it is the active role that people are able to play in monitoring the system and protecting their own rightsthe right to one proportional share for their land during each distribution cycle - that allows the system to function effectively by preserving the egalitarian principle upon which life in the community has long been based.

As far as I know, this concept has not been defined in any previous study, perhaps because it is a feature that has been widely undermined by recent historical events. People's rights-de facto claimant rights (Schlager and Ostrom 1992), otherwise known as communal rights-are qualitatively equal, in that everyone is subject to the same nules and procedures, which they know well. Indeed, everyone in the village knows not only how to irrigate a terrace but also how to operate the entire system, since the male heads of household do this in rotation, also sponsoring and directing the yearly Water Festival, Yarqa Aspiy, the ritual cleaning of the irrigation canals.

Even more importantly, water rights are quantitatively proportional to each other, varying only with the extent of a person's land. In practical terms this means that no one is allowed to deprive other people of water by using more than the amount to which the extent of their land entitles them, or, as commonly happens in Pampamarca, Cotahuasi, and many other places (by a number of means), by getting it more often than everyone else. According to my experience in this valley and elsewhere, including the better-known Colca Valley, such proportionality is crucial, amounting to a basic principle that clearly defines everyone's rights. And where it does not exist, as in most high- land communities today, this is a major source of conflict between "classes"--between land-rich and land-poorand a primary reason for the ongoing breakdown of communal and civic life, for the "tragedy of the commons." Indeed, it is this history of social decline in the other communities - the decline of proportionality-that I was able to trace in my research.

In any case, note that in this village some families have more land and use more water than others, just as in any other stratified community, but that a fundamental symmetry prevails, not only in the size and frequency of household allotments but also in the maintenance duties that people must fulfill in order to preserve their rights. The latter is the most basic of all forms of reciprocity, an exchange between the household and the community, done each year in return for the family's use of communal water (Mayer 1974). And life in this village is very much centered around an equitable arrangement. Because mayoristas have more land and use more water, their contributions to the Water Festival, and generally to the upkeep and repair of the tanks and canals, are required to be greater in terms of labor and other inputs than those of the minorista majority (see Guillet 1992:204-205). More than one member of the family is expected to work, or, where this is not possible, the member who does attend is expected to bring along a generous amount of cane alcohol for the other work-party members. Among largeholders, only widows who have no one to assist them are allowed to hire wage-laborers (peons) to work in their place. Indeed, the use of peons as replacement workers in this communal labor - a highly ritualized event-is generally frowned upon except in cases where no one in a given household is present to do the work. Were this to become a consistent pattern for anyone, it would be considered behavior befitting a valley landlord, referred to here as a misti, and have serious negative consequences. ${ }^{\text {" }}$

Largely because of this arrangement, the infrastructure is well maintained, in contrast to what one sees in the villages formerly dominated by haciendas, and in many other communities throughout the region, where no proportionality between rights and duties exists. The breakdown of these communal work traditions has been widely noted in the Andes for many years (Erasmus 1965; Hendriks 1986), but in my opinion the main reasons for it-a lack of proportionality, and the resentment and conflict that arise among people as a result - have never been understood. The loss of proportionality has generally occuned in the region as communities have become more stratified, due to the accumulation of capital - and effectively also water- by certain wealthy families (Trawick 1994a, 1994b, in press).

The principle of symmetry or relative equality as I have just defined it, or "equity," as it has been more appropriately called (Hunt 1992), is based on long-standing continuities in the irrigation system, which are also commonalities shared by the community members: uniformity and 
proportionality. It is important to note, however, that these commonalities form the central pillar of a way of life that features numerous other forms of cooperation. Distinctive norms govern social interaction and exchange in various domains and are the key to relations between social strata. ${ }^{12}$ Ultimately, however, these standards are expressions of the will of the majority, who, through a continual process of vigilance, negotiation, and confrontation, have been able to maintain constraints on the terms under which the wealthier minority operates, not just in irrigation but also in reciprocity and social life in general.

These terms of exchange are markedly different from those that prevailed traditionally in the hacienda-dominated districts, indeed quite consciously so. In Huaynacotas people work together side by side in all kinds of labor relations, including the most unbalanced and seemingly asymmetrical forms (mink'a, the exchange of a day of work for a party in the fields and a share of the harvest), as well as in situations of hired or wage labor (jornal). This was explained to me numerous times, as in the following example: "Kay llaqtapi aylluyuq minkakunapi kuska igualmanta llank'an" (In this community ayllu members work together in mink'a as equals). This kind of mutuality, which amounts to an explicit norm or expectation, affirms the common attachment of everyone to subsistence work and expresses a moral principle that is central to village life: the idea that people are mainly responsible for their own cultivation and that, although they have to rely on others for help of various kinds, no one subsists or lives primarily off of the labor of others. This commonality helps to sustain an internal domestic life that, while not without fundamental oppositions and conflict, seems remarkably civil and cooperative based on my experience elsewhere in the valley and in southern Peru in general (cf. Hendriks 1986).

In this community agricultural labor is not a commodity to be purchased in order to rid oneself of a burden, or to free oneself to do other things, as in most other places, but the central reality of a way of life that is shared. Reciprocity, still the primary mode of social interaction, involves the sharing and exchange either of such work itself or the products of one's own physical labor, regardless of a person's status within the community. And that, I think, imparts a distinct kind of value to the goods and services exchanged-not just a "use value" but a value involving the expenditure of one's own time and energy. This is the commonality that underlies reciprocity, a bond that unites people of different socioeconomic levels in an unusual way-one that, at least in this case, lies at the heart of the peasant way of life and helps to define the identity of local people as both comuneros (village members) and campesinos (peasants). Mayer pointed this out long ago, explicitly in reference to mink'a, a form of group labor done for the host and landowner in which a day of work is given in exchange for good food, plenty of com beer and cane alcohol, coca, and a party afterward, also often including a portion of the harvest. Yet few people seem to have recognized the significance of his observation:

In summary, it is the expenditure of personal effort for the benefit of others that is taken into account in reciprocal exchanges in Andean society. One recompenses this only through the return of the same kind of personal effort. Under these conditions there is a symmetrical exchange, and both parties feel satisfied with it. [1974:44, translation mine]

The symmetry arises directly from sharing in the "peasant labor process," which Trouillot (1988:4-9) has aptly characterized, noting its household organization and other features, but without appreciating its personal nature, the unique value imparted by it, or the special kind of interhousehold bond that can consequently be formed through reciprocal exchange. But what, it might be asked, does all this have to do with irrigation?

Note that water is extremely scarce in the village, with irrigation cycles two to three months long, and that people do occasionally fight over the resource because it is sometimes stolen, given illegally, or otherwise taken out of turn. The larger landowners in particular, who get more water than most people, must assert and protect their rights personally, and quite publicly, with a shovel in the act of irrigating. Due to the various risks and responsibilities involved-water theft, the risk of canal obstruction and flooding up above one's parcel, and resulting damage to another person's field--they cannot afford to simply turn this task over to a wage laborer, someone to work in place of members of the household. Among other things that would be considered behavior befitting a valley landlord, a misti, and, as a violation of the aforementioned principle, it would not be tolerated but instead readily taken advantage of. It may seem odd that such a contentious situation should help to sustain a fundamental commonality, that of personal responsibility for most subsistence work, but that is evidently the case. This idea, that no one is above certain kinds of work--irrigation and cultivation, group tasks such as mink'a, and communal maintenance work-that people do not hire others to replace them in these tasks and do their work for them but only to assist them, is the main principle governing labor relations in Huaynacotas. ${ }^{13}$

This kind of power to impose limits and constraints, ones that perpetuate basic commonalities and mutual interests among individuals, so democratic in essence, is thus rooted in irrigation. It is inherent in the autonomous moral and political structure that the hydraulic tradition itself, an authentic Andean one, has provided, and which the people in this village have struggled to preserve. Note that the larger landowners here, although possessing no more than three irrigated hectares each, are involved in the same activities as the landlords in Cotahuasi and Pampamarcasubsistence combined with some cattle-raising for the market and a minor amount of petty trade-and that a few of 
them even have small herding estates on the altiplano above the village (herding grounds that long ago belonged to the community) where they keep llamas, alpacas, and some cattle, much like the landlords of the lower valley. Now, as in the recent past, they would have to be seen as roughly equivalent to other large-holders in terms of class. Yet their behavior is distinct in fundamental ways: they are accountable, as comuneros, to the interests of the other village members. They are subject to certain constraints that those members impose on their activity, an accountability that is integral to their social identity and rooted in the exercise and defense of their water rights. ${ }^{14}$

\section{Implications for History}

One has only to look again at the account of Garcilaso to be struck by the possibility that what local people say is true, that Inca practices have survived in this village and even flourished in a modern setting. A careful examination of the passage reveals that nearly all of the basic principles previously discussed are either mentioned directly, or can be logically inferred, from his brief description written so long ago. Proportionality is the main one emphasized, but that also implies uniformity, at least in the watering frequency, since without that there can be no real proportionality among water rights. His account also implies some sort of uniformity in technique since, without that, how could the amount of time and water needed per unit of land be known? Contiguity and regularity, of course, are mentioned directly. However, all of these principles together confirm as well the presence of the fifth one, transparency, for reasons already explained. Although other explanations are possible, this correspondence between contemporary practice and an account of life in the distant past-one that many people consider idealized and inaccurate-can hardly be a coincidence.

If we accept, simply for the sake of argument, some degree of truth to Garcilaso's claims, how then were the Incas able to divide the water proportionally, giving everyone the amount they needed without favoring anyone? Surely they didn't wear sundials on their wrists. The secret lay in the method of landscaping and the technique of water utilization, in level terraces and pooling structures of uniform height, in watering every parcel of land in the same way. The standardization of irrigation time and of water consumption are inherent features of this technology. Just as importantly, the key lay in having everyone's land irrigated on the same cycle,$^{15}$ as Garcilaso implicitly acknowledged.

It is hard to imagine any other way that proportionality could have been achieved in an Andean setting. According to the evídence presented here, we can question whether relations between the Incas and their subjects were as equitable as the chronicler said, but it is difficult to doubt that, if they were, then this is how it was accomplished. Nevertheless, accepting the possibility that he was inaccurate or that he exaggerated, then perhaps water rights were only this equitable within the villages, between the commoners and their leaders, the kurakas or native elites. Otherwise the passage would have to be a total fabrication, which seems highly unlikely given Guaman Poma's ( [1613]1978:356, $246,848,1040,1237)$ repeated emphasis on justice and fairness. In the political field of irrigation and water rights, the concept of fairness, I would insist, necessarily encompasses both uniformity and proportionality, principles whose great significance has only slowly been recognized during decades of research by students of irrigation throughout the world (Coward 1979; Glick 1970; Hunt and Hunt 1976; Ostrom 1990). The ideas are featured in both accounts, which cannot therefore be a fable or a mere projection into the past.

In sum, what kind of water "policy," if such ever existed, could Garcilaso have been describing? It would hardly be surprising if he were right, since the Incas are known to have adopted as official policies many institutions and traditions established by previous Andean cultures and civilizations. Archaeological and ethno-historical research have repeatedly shown that this characterized them as an imperial power (e.g., D'Altroy 1987; Levine 1987; Murra 1975, 1980; Murra and Wachtel 1986; Netherly 1984). The dual or moiety ${ }^{15}$ form of social and political organization is the best example we have of a much older Andean pattern, known to have been adopted by them as a way of organizing subject communities and extracting tribute within the empire (Duviols 1973; Zuidema 1964). It is one that the Spanish made use of throughout the colonial period for much the same purpose, and it is still quite common among indigenous communities in the region today (Gelles 1995).

Based on the ethnographic information now available, not just from my study but from many others done in different parts of the Andes, the water policy itself, like the original social organization, appears to have been a dual one, meaning that it had two modes of operation. One of them, I think, was predominant, typical of the normal state of affairs-water scarcity - and we see it at work today in Huaynacotas and other villages like it. These include two other communities in the Cotahuasi valley, at least two in the nearby Colca valley (Guillet 1994), and many others throughout the highlands, where scarcity is the rule (Guillet 1994:184; Mitchell 1976).

However, it is highly likely, and quite consistent with Garcilaso's comments, that distribution took place according to different principles-hierarchical ones based on age and prestige--when enough water was available to do so. This kind of arrangement, which comes down to distributing water according to social criteria, to households and landowners rather than to specific fields, is also widely found in the region today. As for its hydrological dimension, in most cases the basis for hierarchy in water distribution 
today is gerontocratic-according to a prestige ranking based on age and service to the community (Fonseca 1983; Gelles 1986; Guillet 1994; Mayer 1985). Treacy (1994a: 222) observes that this arrangement, locally referred to as the saya system, formerly operated when water was adequate or abundant in the village that he studied. Note, however, that distribution under this regimen is hierarchical in symbolic terms only, since all landowners receive their full share or turn during each cycle of their respective system. The difference is that social ranking determines the order in which they irrigate in a given area, and not the lay of the agricultural land.

Such a hierarchy is followed today in Pampamarca, the second village in my study, where, as in most places, it is linked with the cargo system of ceremonial sponsorship. How can this striking pattern be explained: the widespread existence of two apparently "indigenous" hydraulic traditions that seem at first glance to contradict each otherboth, it should be added, are associated today with the dual social organization known to have once existed throughout most of the region. I suggest that they were originally parts of a "dialectic" tradition, one that alternated between modes designed to deal with conditions of water scarcity and water abundance. However, in Pampamarca and many other places, the hierarchical principle appears to have been adopted as a permanent arrangement during the long era of depopulation when water became abundant and remained so for centuries, eliminating the need for conservation (Trawick in press). That, of course, is a situation that no longer prevails in the region, although interestingly enough it still exists in Pampamarca. And unfortunately, what apparently happened in most places is that the other tradition was simply forgotten and lost. Why this did not happen in Huaynacotas I cannot say-perhaps because people preferred the simplicity and efficiency, even elegance, of an egalitarian tradition. Or perhaps they reinvented the tradition when water once again became scarce, rediscovering the simple principles that had been worked out long before.

Thus, communities in Inca times may have alternated periodically between strict equity and efficiency and a kind of prestige hierarchy, in a sort of "gumsa/gumlao" arrangement, to use Leach's (1954) famous terms. ${ }^{17}$ However, since climatic and demographic conditions appear to have been quite similar to those of today, I would suggest that use of the hierarchical principle was intermittent in most places, rather than routine, and essentially symbolic, since a shortage would have been the normal state of affairs. Recent studies have shown that the empire emerged during a long dry period lasting several hundred years (Thompson et al. 1985) and that the Incas expanded irrigation in the provinces partly in order to cope with the climatic shift (Treacy 1994a). This probably means that the contiguous system was used most of the time in most places in the Andes.
It is important to point out, however, that the difference between the two modes with respect to water conservation and even equity may not originally have been that great. As I saw in Pampamarca, it is possible to distribute water hierarchically in a way that closely approximates a contiguous pattern simply by (1) confining distribution to one small sector of land and one group of landowners at a time and (2) giving shares to people of the same rank in a sequence determined by the location of their plots, starting on one side of the sector and moving systematically across it. This pattern, although not common today, minimizes the difference between the two methods in terms of surface area and the amount of water lost, and, provided that everyone gets their share during each irrigation cycle and uses the same watering method, it preserves, at least in theory, the basic equity among rights. It does, however, have other features - mainly being inherently flexible and thus less transparent to the water user - that make it more problematic than the alternative, which I cannot discuss here but do elsewhere (Trawick 1994a, 1994b, 2001, in press). In any case, given the scarcity that is a fact of life nearly everywhere in the Andes today and the serious problems that result, such as water theft, corruption by water officials, and constant disputes over the resource, it is clearly the more transparent and conservative system, as exemplified by Huaynacotas, that is most relevant to policy and to solving those problems, one of my major concerns.

This system would have fostered a high degree of accountability and given local communities a remarkable capacity for managing their own resources. Admittedly, both Garcilaso and Guaman Poma are known to have exaggerated at times the wisdom of Inca governance, but these principles define a distribution system that (see Trawick 2001 ) is by far the most effective. It provides people with a strong incentive to conserve water and abide by the rules, since by doing so they are directly maximizing the frequency of irrigation, a benefit that affects everyone in the same way and to the same extent. The principles create a feedback link between individual behavior and the common good that is direct and obvious to the farmer and that cannot be achieved as well through any other kind of arrangement.

In a highly transparent system, people are quite confident of their ability to see what is going on, to detect and punish any infractions that occur, and to protect their own rights. And that has everything to do with their strong tendency to obey the rules and respect tradition. It also, I think, explains why the people of Huaynacotas may have held on to and continually ratified their way of doing things over such a long period of time. I suggest that the Incas endorsed the tradition because of this, its general superiority, and because, like the moiety organization, it had already emerged and become established widely throughout the highlands, perhaps in Huari times (Duviols 1973) or even long before. 
The main problem with this hypothesis is that it seems at first glance to be contradicted by the remarks of other chroniclers, some of whom are generally considered more reliable (Mitchell 1980). In discussing the Inca agricultural cycle, several early writers-most significantly Cobo ([1653]1964:120-121)-stated that, throughout the empire, land was divided up among the Sun (the state religion), the Inca (the State itself), and the peasantry, and that the peasantry always cultivated those lands in that sequence. Several also stated, seemingly contradictorily, that the payment of labor tribute on imperial lands was somehow timed in such a way as not to interfere with peasant agriculture.

Since the planting order necessarily determines the watering order, all of this would seem to indicate that the contiguous sequence described by Garcilaso could not have been followed-assuming, of course, that the three kinds of land relied on the same water sources. Mitchell (1980) apparently makes this assumption in an impressive attempt to use contemporary ethnographic data in assessing the accuracy of these same accounts of the Inca past. He shows that climatic and ecological constraints strictly determine the planting order and that these would have militated against the hierarchical sequence of agricultural work, which would seem to indicate that Cobo and the others are wrong. On the face of it, this would also seem to perhaps vindicate Garcilaso's claims about the contiguous order of water use; however, I do not think that all of these observations necessarily contradict each other at all.

My research in the Cotahuasi valley on the location of the imperial lands of the Inca and the Sun confirmed the early observations of Murra (1960) and the more recent findings of Denevan et al. (1986) in the Colca valley, and lent support to the assertions of many other ethnohistorians and archaeologists (e.g., D'Altroy 1987; LeVine 1987). Wherever possible the Incas opened up new lands for cultivation and the extraction of labor tribute, generally along the valley bottoms. They did this by tapping previously unused water sources-the rivers-a feat that generally involved the construction of major canals requiring a great amount of manpower (Trawick 1994b:81-85, in press). There is good evidence in Cotahuasi that, just as the local people claim, the Incas developed a vast plain on the valley floor by building a long canal and aqueduct to draw water from the previously untapped Cotahuasi River. ${ }^{18}$

These lands had their own abundant water source and, being warm and virtually invulnerable to frost, they could have been sown at any time, perhaps first in the sequence, as Cobo and others said. This was probably done during the winter frost season, before the adjacent mountainsides could be planted, so that it did not interfere with local planting and watering cycles in any way. According to my experience in the region, these royal lands are easy to identify due to their location, their large expanse, and the fact that they are fed by long canals. ${ }^{19}$ They also tended to become the sites of major haciendas during the colonial period for obvious reasons. In any case, if the opening up of such new lands was indeed the Incas' policy, then there is no contradiction between Garcilaso's claims about water policy ${ }^{20}$ and the claims of other chroniclers about the sequence of cultivation. The arrangement would have allowed a material but also highly symbolic recognition of the Incas' hegemony and superiority without interfering with communal water use for subsistence in any way.

How and why may such an egalitarian hydraulic tradition originally have emerged? The question raises the Wittfogel hypothesis concerning the manner in which irrigation can shape social and political life simply by encouraging, or ultimately even requiring, unification-the establishment of a central authority and certain "collective-choice rules" (Hunt 1988; Schlager and Ostrom 1992) for managing the resource. In considering the constraints that the technology may have imposed in ancient times, I would suggest that they were much the same as they are today. In this formidable and remote mountain setting, autonomous control of local water supplies, rather than management by representatives of a distant central government, was, and is, crucial. If one assumes, therefore, that population densities and man/land ratios were high in the Andes, and comparable to those of today (see Cook 1981), so that water must have been in short supply most of the time, then the smallscale canal systems of the sierra can in fact be said to have encouraged the emergence of a certain type of village society.

We know that this was a peasant society based on subsistence agriculture, and I think we can therefore safely assume a uniformity among household water needs. This is to say that every household in a given village probably grew the same diverse and mixed array of subsistence crops-often intercropped in the same field, as we typically see today--with the same water needs. As I saw during my research in the other valley communities, it is the commercial crops-alfalfa in the highlands (see Guillet 1992), sugar cane and other export crops in lower areas-that cause so many problems in irrigation today due to their higher water "requirements." These encourage inequity and conflict among landowners because they are typically grown by a minority of people, and they of course were introduced by the Spanish. There clearly was no market during Inca times nor were there any "improved" varieties of maize, potatoes, or other cash crops, which also encourage inequity today due to what are thought to be their peculiar water "needs."

Under these conditions - a prevailing scarcity and a uniformity among household water needs-and assuming above all that conflict over the resource had to be minimized, some options were better than others and one was best of all because it was not only efficient but also transparent and fair: the kind of system found in Huaynacotas 
and other villages like it. Although the tradition may well have emerged here endogenously, and in many other places too, I suggest that the Incas endorsed it and may even have imposed it in certain locations, namely in the various state surrogates or colonies (mitimaqkuna) that they installed widely throughout the countryside.

In this particular case, the control of water is unified or centrally directed, but the system is not articulated with any outside agency and is, at the present time, fully autonomous. Elected leaders oversee it and resolve conflicts, but power and authority also have a diffuse quality since monitoring is dispersed among households and spread out all over the canal system rather than being concentrated in the hands of the Distributor. This is fortunate because Peru's national government, which theoretically owns all of the country's irrigation water according to existing law, has never administered the resource in Huaynacotas, nor has it in many other places, perhaps even the majority of highland communities. Outside of political and economic centers like Cotahuasi, the State has typically had little influence on irrigation, although it has tried to intervene in places like the Colca valley (Gelles 1994; Guillet 1992, 1994), encountering resistance there and ultimately fostering a lot of conflict. ${ }^{21}$ This too is fortunate because where it has intervened and implemented the water law, as in Cotahuasi district, the system of state control has invariably been a dismal failure (Guillet 1992; Trawick 1994, 1995, in press). Indeed, that is why the State is now trying to get out of water management and has formally turned that responsibility back over to the local communities. ${ }^{22}$

The Incas probably did not invent this system, but they do seem to have appreciated its advantages-a tradition that may have survived in other communities yet to be studied. Treacy (1994b) provides the only ethnographic example of the entire Inca system in operation: a village in the Colca valley where-precisely as must have happened centuries ago $^{23}$ - water distribution shifts from an equitable and contiguous arrangement to a more flexible and less efficient one-formerly hierarchical and based on gerontocratic principles-when enough water is available. On the basis of this case alone, I would say that Murra and Wachtel's well-known comment that "there is no way of projecting seriously from present-day practices to institutions four centuries earlier" (1986:2) was premature. Instead, I would point to another of their observations: "Colonial society was constructed from many more such Andean components than is generally recognized" (p. 6).

Of course, I cannot prove that the Incas did things this way, nor can I prove that the equitable tradition predominated at most times and in most places. But the hypothesis has important implications for policy regardless, based as it is on practices in many contemporary communities. According to what I have seen, not just in Huaynacotas but in other places in the valley as well, this was a policy for building certain kinds of institutions and "developing" a particular kind of society, one that could manage its own resources with minimal waste and conflict because its members had certain basic values in common--both material and moral--and were accountable to each other in fundamental ways. This kind of community was fully independent in terms of resource control and highly efficient in this kind of arid alpine environment. It continues to be so today and, if it were re-instituted in places that are in need of it, such as Cotahuasi district, where the State has prolonged and intensified a long legacy of tragedy and water conflict, it could greatly alleviate scarcity and help to resolve one of the most serious problems in contemporary life. $^{24}$

To me this tradition was, and still is, the core of the Andean way of life. Irrigation and the equitable sharing of water were, and in some places still are, the very heart of it. And that way of life has persisted to this day in some parts of the highlands in spite of the market and all the changes that the cash economy, rapid population growth, seasonal and permanent migration, and a growing familiarity with life in the city have brought about. These experiences have long affected Huaynacotas, just as they have nearly every other community in the highland region, no matter how remote; and local people are very much a part of a changing world with its increasingly global economy. If I am "essentializing" Andean culture here (Kearney 1996; Starn 1991), it is only because I believe I have seen its essence in certain forms of practice, in concrete ways of doing things that are ancient but that still exist in some places. I have also traced in detail both how and why those practices were undermined historically, in the vast majority of cases, and lost in favor of other, less equitable and meaningful ways of doing things (Trawick in press).

\section{Conclusion}

My intention in this article has been to describe an extraordinary place, with its customs and claims of heritage and ancestry. But I think that communities like Huaynacotas show that there is something significant that many of us who work in the region have somehow missed, or dismissed, about Andean people. Today culture is all too often seen as nothing more than a kind of window dressing, certain ethnic trappings--language, dress, claims of common ancestry-that subaltern groups adopt in order to distinguish themselves for political and economic gain, usually in response to policies and circumstances dictated by someone else (e.g., Ernst 1999). This strangely derivative view of culture, seeing it as a contemporary product of political economy rather than something built around a much older construct that is in part an adaptation to the environment, may be appropriate in many cases, especially in situations of what we have come to call resistance (Escobar 1995; Scott 1985). But I think it has become far too predominant, reflecting in part the fact that many of us long 
ago lost interest in the concrete and practical things that people have to do on a daily basis in order to survive both as individuals and together as a community.

For much of the world's population, however, that is still primarily the work of cultivation, of families feeding themselves and actually "making" a living. And it is through such necessary and routine activity that fundamental differences among peoples can arise. This is often the case when subsistence requires the sharing of essential resources held in common, but it is particularly true of water. That is what I have tried to show here: how the material reality of having to share scarce water in order to subsist and survive - making the best of a bad situation-can bring people to interact and coexist in an extraordinary manner and ultimately even come to see the world in a distinctive way.

People are quite capable of working out a solution to this challenge, contrary to what Hardin (1968) said long ago, an adaptation that affects everyone in the same way and is best for all in the long run-an equitable arrangement whose symmetry resonates throughout many levels of society and culture. I have described here a tradition that I call the moral economy of water-in honor of James Scott (e.g., 1976, 1985) for his work in Southeast Asia, and Enrique Mayer (e.g., 1974, 1977) for his stubborn defense of the concept and the way of life in the Andes. In trying to define it-ethnographically, ethnologically, and historically-my main goals have been to stimulate debate and guide future research, since I cannot prove that such a tradition even exists. I can point to the practices and principles of organization upon which it is based. I can argue for their antiquity, their efficiency, and their relevance to policy, to solving the serious problems that afflict water management in the Andes today (Trawick 1994b, 1998, 2001, in press). But in going beyond that to speak of it as the moral foundation of a distinctive way of life and worldview, I can only assert this as one interpretation of the world that I see around me in Huaynacotas and other villages like it-though not exclusively there, as I will explain below.

In doing this I have also tried to contribute to the emergence of a new kind of ecological anthropology, one that builds on Rappaport's $(1968,1979,1993)$ many insights but takes a more dialectical approach to the nature/culture relationship and adopts a focus that is at once historical, material, political, and even symbolic (Biersack 1999; Kottak 1999). In summary, then, let me reiterate how I characterize the way of life, why I think it is distinctive, and how I account for its unusual qualities. These are my conclusions, which my readers, of course, are free to take or leave and draw their own.

The way of life in the village is distinct, different from life in the First World or the West, because it is based on a common attachment to the soil, to water, and to agricul- tural work. More precisely, it is based on an attachment to a specific, historically created place or landscape (see Lansing 1991) where this work is done in a certain way, thought to be the right way or the proper way. Central to the tradition are the ideas that people are responsible for doing most of their own work and that everyone, all members of society, has the right to a share of the basic resources necessary for subsistence and survival. That right, however, is contingent on certain duties to the community that must be fulfilled.

The concept of proportionality is crucial in all of this, since people's rights to the scarcest and most vital resource must be proportional to each other, even equal in a basic way. Among other things, this ensures that no one individual's share can ever grow so large as to jeopardize the rights and livelihood of everyone else. Moreover, the duties of people to give back to the community are proportional to the benefits that those people derive from living there and using its resources. These are ideas and values expressed in rules and procedures that are thought to be just, and their significance from an adaptive point of view is that they have made life here sustainable, preserving the livelihood that people have in common while preventing the differences between people--material and otherwisefrom becoming too wide during a time of fairly rapid change. They are extraordinary, like the village and the landscape itself.

According to my understanding, however, this is not just the way that people in Huaynacotas live, in an "operational" sense, and perceive themselves to live, in a "cognitive" sense, to use Rappaport's terms-two models or understandings that in this case closely coincide. I have spoken also of a moral model, an image of the way they think that life and human society in general ought to be. From what I have seen, the model is shared by most local people, an impression that I cannot claim, however, to have tested and confirmed. I can only say that I see it expressed in their practical activity and manifested in other ways from time to time.

Nevertheless, I think that on a conceptual level the moral model extends all the way from the concrete, particular, and local to the much more general and abstract. Seen as a set of ideas about the fundamental right of runakuna, or human beings-the right to subsist in a society built around a basic material symmetry or proportionality-the tradition extends almost to the level of Rappaport's (1979) "cosmological axioms," though people see clearly that the outside world does not work in this way. The model, then, is critical and does express a kind of protest. But it is not merely derivative, something that people worked out during the colonial period or thereafter in order to respond to external conditions and events. As I have tried to show here, it is ultimately local in origin and clearly much older than that, older even than the Incas. In 
this sense it is different from the kinds of local models that Escobar (1995) characterizes so well.

I cannot say where the model comes from, whether from the ground and water up or from "the spirits"-the human mind and spirit-down. Contrary to what one might think, if forced to choose I would opt for the latter. After all, the central value of equity or fairness, like the rules for water use that manifest it, is a response to the social, not the natural, environment. It is a solution that people have worked out to the problem of living together and sharing something vital and scarce, and the concept of equity-basically a recognition of the inherent worth of every member of the community - allows them to do this in a relatively peaceful manner. Neither this concept nor the idea of a common right to the resource sprang from the mountainsides of Peru. Furthermore, I think that the moral model and its central value, as cognitive phenomena, are still widespread in the Andes, that they persist even where the material foundation for them has been lost-in places like Cotahuasi, where colonization, domination, and the "tragedy of the commons" have occurred. In this sense I agree with Mallon (1983) and Smith (1989), who see an egalitarian ethos persisting in many peasant communities as a set of aspirations and concerns, even where the conditions of people's lives are highly unequal and harsh.

In any case, as for its ontology, I think that those of us who are ecologists have finally learned not to ask the old question that would break the dialectic down. The moral economy of water is a product of the unfolding of nature and culture together, of their mutual transformation. It is the outcome of a process whereby the human mind and spirit have expressed themselves within a material reality that is itself partly, but only partly, a social construction. It partly reflects necessity, the impact of material constraints, but it is also, in the final analysis, an expression of certain eternal elements of human desire and intent. In the Andes, this way of life and worldview emerged long ago in the sharing of water, and irrigation has helped to preserve it and hold it fast ever since.

\section{Notes}

Acknowledgments. Many people contributed to the writing of this article, and even more to the research on which it is based. I wish to thank Harold Conklin, Richard Burger, and Enrique Mayer, all of Yale University, for their interest and encouragement through the years. Mayer's work was a major inspiration, and his help was crucial in straightening out some problems of interpretation. Subsequently, Robert Hunt of Brandeis University, Paul Gelles of the University of California at Riverside, and Lanfranco Blanchetti of Johns Hopkins University read earlier versions of the article and made valuable suggestions that helped me get it into publishable form. At the University of Kentucky, William Adams and Tom Dillehay did the same, as did David Killick and Ana Alonzo of the University of Arizona. In the final stages of revision,
William Mitchell of Monmouth University was a tough and especially helpful critic. The article is dedicated to the memory of my good friend and colleague, John Treacy, who no doubt would have helped me with it also, whose work was another major inspiration, and who is sorely missed.

1. Most researchers found communities where water control was highly "centralized" or unified (Bolin 1990, 1994; Fonseca 1983; Gelles 1994, 1995; Mayer 1985; Mayer and Fonseca 1979; Treacy 1994a, 1994b; Valderamma and Escalante 1988), occurring according to certain rules and procedures (Hunt 1988; Kelly 1983), while others had described ones that were "acephalous," or lacking any effective central authority (Guillet 1992, 1994; Seligmann and Bunker 1994). Still others (Mitchell 1976, 1994) described systems that alternated between unified and acephalous modes of operation, depending on the time of year and the state of the water supply. The first type sometimes operated rather smoothly according to those customary procedures, but did not necessarily do so by any means, whereas the second tended to be rife with competition and conflict over water rights, in most but not all cases (Paerregaard 1994). With regard to modes of distribution and watering methods, the diversity was equally striking. In some villages, sectors of land and their individual fields were irrigated in a fixed sequence on a single schedule, while in others this was done in a flexible, irregular or even haphazard order. Some communities were characterized by flat terraces watered from the bottom upward, others by sloped fields watered from the top downward, while most seemed to show a mixture of landscaping and watering techniques.

2. This remained true throughout my fieldwork until 1989, when the State turned responsibility for water administration over to local communities. The resource is still owned by the State but is now under local control.

3. These other communities, without any haciendas within their territory, are Cahuana and Ayahuasi. Everything I have seen and been able to learn about these villages convinces me that they have the same hydraulic tradition, but I have not yet been able to confirm this with certainty for all of the details involved.

4. It is thus engineered, constructed, and postnatural-a place or landscape in the sense that Lansing (1991), Biersack (1999), Kottak (1999), and others now use these terms, the products of a dialectical and mutually transforming relationship between nature and culture.

5. Note that a slightly different technique is used for the first irrigation of the year, a light irrigation called phasphay, which does not involve pooling. It is used only once to plant maize terraces and, since it is done in the same way by everyone, it does not alter the basic proportionality among water shares. Treacy (1994a, 1994b) describes the same situation in the Colca valley. It was also formerly used, normally only once a year, on the abandoned fallowing lands (see Trawick in press).

6. When I speak of rules, I refer to what is considered the right way or the best way of doing things and do not necessarily imply that there are any sanctions to enforce them. Indeed, I do not think that most of them have ever been tested in this way, precisely because they are considered logical and optimal. Note again that, as regards watering technique, I am referring to the maize-growing zone, the lands under intensive 
irrigation-the vast majority of the territory. The area of sectorally fallowed lands, the t'ikras, is primarily rain-fed and is normally irrigated, through a slightly different technique, only for planting. Again, these lands now lie abandoned because of a long drought that began in the 1970s.

7. As I have shown elsewhere (Trawick 1994a, 1994b, 2001 , in press), alfalfa is an extremely thirsty plant that has had an enormous impact on life in the Andes. The changes widely associated with its cultivation elsewhere are the destruction of terracing and the re-creation of sloped landscapes, the development of a new and more wasteful watering technique, and, most important of all, the privatization of communal water by estate owners.

8. At times of real emergency, when the period between waterings begins to exceed 90 days, the water distributor truncates the distribution sequence by taking certain sectors of land-the irrigated fallowing lands, or t'ikras-out of production. The impact falls evenly on everyone, since everyone has land in those sectors.

9. This is only a relative autonomy. The neighboring communities previously mentioned, occupying lands that formerly belonged to Huaynacotas, share the two water sources and have exclusive rights to use them on certain days of the week. Autonomy in this case refers to local control over the rules and procedures governing water use.

10. The near-equivalent for this term in Quechua is llaqtamasi, but the Spanish word is often used as well, since most people under age fifty are fully bilingual.

11. The shunning of all kinds of manual labor, and particularly of communal maintenance work, has historically been the most distinctive marker of the elite status of local landlords and other people who consider themselves to be of direct Spanish descent. Everyone in the valley knows this, including people in Huaynacotas, who have worked on the valley estates as occasional wage laborers over a long period of time. This is one of the reasons, though not the only one, why such behavior is bighly stigmatized as elitist and anticommunal in nature. The situation is largely hypothetical, however; it does not happen, and I have only described what I was told when I asked.

12. It is important to note that no one in the village has more than five hectares of total land, including the abandoned (irrigated) fallowing lands, and that two to three hectares is the average under irrigation by the mayoristas, who make up less than 20 percent of the population. Certain customs regulating the sale of land have apparently prevented the differences within the community from becoming too wide (see Trawick 1994b).

13. I suspect that this is now the case in many communities. Indeed, I believe this is what Mayer (1974; also Mayer and Zamalloa 1974) has always insisted, though I perhaps am putting it here in slightly different terms. Again, in Huaynacotas, the host or landowner and his helpers work together in all kinds of work relations: ayni (balanced reciprocity), mink'a, ("asymmetrical," unbalanced reciprocity), even jornal (wage labor). Assuming the posture of being "worked for" and replaced is not tolerated and would have serious negative consequences. This contradicts what Painter (1992) and other political economists have long argued about reciprocity. However, I strongly suspect that now, after the 1969 agrarian reform, when exploitative forms of mink' a were outlawed, this has become the predominant pattern in many areas. In Cotahuasi, for example, what the campesinos (peasants) have done is to redefine mink'a in these terms and confine its use to within their own society, refusing to work in this manner any longer for anyone who is not considered a campesino. They have reclaimed the tradition for themselves, taking mink'a back from the landlords, who of course never actually worked in, but only hosted, these events (Trawick 1994a: chap. 6).

14. The idea of equity or proportionality is also basic to another village institution: the cargo system of ceremonial sponsorship. Central to this tradition, which has been characterized by some authors as a kind of leveling mechanism, is the idea that people who have more should give more, roughly in proportion to the wealth that they have been able to accumulate. The institution is an essential part of the moral economy (Scott 1976), but it is not directly related to water and irrigation.

15. That is, every parcel of land watered by a given water source; that is, every plol within a given canal system.

16. In the Andes, moiety organization refers to communities composed of two halves, upper and lower divisions called sayas, which are known to have traditionally been endogamous and to have lived in a kind of ritual competition with each other. Indeed, the upper half is known to have, at least symbolically, enjoyed somewhat higher status. Andean moieties are thus distinct from the exogamous ones described in so many other regions, which enjoyed closer and more amicable relations. In the more rugged hinterlands, the two sayas seem to have often, though not always, had their own separate territories and irrigation systems (Guillet 1994).

17. I am greatly indebted to Enrique Mayer for making me see this, and for many other insights provided by his work.

18. The aqueduct, which fell out of use immediately after the Spanish conquest, was being repaired and rebuilt during my time in the valley in order to reclaim the lower part of these lands. A great number of potsherds were found in the fill of the canal wall, a collection of which I took to an expert for analysis. All of them proved to be Inca utilitarian ware (De la Vera Cruz: personal communication), indicating that the canal was indeed built by the Incas.

19. It seems likely that this was also the pattern in Quinua, the district studied by Mitchell $(1980,1994)$, and that Cobo was indeed right.

20. This is even true of Garcilazo's own, slightly different position on the order in which the different lands were sown (see Mitchell 1980:140).

21. It is important to note that Peru's Ministry of Agriculture has, wisely enough, strongly promoted contiguous distribution as the normal routine (called de canto a canto) in Cotahuasi, as in the Colca Valley and elsewhere. Unfortunately, because the agency is unaware of all of its virtues, they have done this while allowing numerous kinds of exceptions to the rule (see Trawick 1994b: chap. 8). Given my argument that it is so efficient in ways that the Ministry is not fully aware of, and central to both equity and ethnicity, it is interesting that people in some of the Colca communities (though not all) have resisted adopting it as a permanent arrangement, although nearly all of them now use it under conditions of scarcity, as they appear to have been doing for a long time. In one 
case, Corporaque (Treacy 1994a, 1994b), the larger and more powerful landowners object to it when water is adequate, complaining that this regimen does not allow them enough time to adequately water a big field. In another village, Cabanaconde (Gelles 1994), resistance is directed against a coalition of the largest landowners, who in the past tried to appropriate the six days of water saved under the contiguous system in order to expand irrigation and use it on their own dryfarmed fields. The State subverted its own effort in this case by endorsing the expansion, thereby negating completely the benefits of the change, a higher frequency of irrigation, for the majority of water users. In any case, note that, although the system is clearly not a panacea for all social ills, it is used nearly everywhere in the Colca as a way of dealing with scarcity and is indeed found in many parts of the Andes, generally in villages where the moiety organization has survived, as Guillet (1994:184) has noted. This supports the view that contiguity was the normal procedure under the saya system during Inca times.

22. The government formally did this in 1989, unfortunately without providing communities like Cotahuasi with any viable model for managing the resource themselves.

23. Further support for the hypothesis can be seen in the work of Zuidema (e.g., 1986) and Sherbondy $(1986,1994)$ on the organization of irrigation in imperial Cusco, the Inca capital, known to have served as a kind of organizational model for communities throughout the empire. Their study of the moiety organization, the canal systems, and the system of ceques-linear sight-lines, defined by sacred sites radiating out from a center-establishes a number of points whose importance is, I think, increased by the evidence I have presented here. Their work shows that one of the functions of the sightlines around Cusco was to aid in keeping track of water distribution within moieties, with their component social groups (panacas and ayllus), each of which had its own territory watered by a long canal shared with the other groups. This is to say that the practical function of the lines was to assist in keeping track of the movement of water through space and the recognition of the groups' communal water rights. As both of these authors and Treacy (1994b) have all noted, the geometric arrangement of the lines, roughly delimiting the territories of neighboring social groups but mainly serving as "meridians," or spatial reference points (Sherbondy 1994:86), strongly suggests that water distribution moved systematically from one side of the valley to the other-first through one moiety territory, then through the next. But according to what kind of pattern?

I suggest that the answer is finally here, in the ethnographic and historical information now available, as Treacy (1994a) did before me. When water was adequate or abundant, it was distributed in an order determined by the rank of the social group and perhaps of the individual landowners within each group territory. But when it was scarce, it was done according to the simplest, most equitable and efficient arrangement. Indeed, I think that the information now at hand makes it possible to appreciate fully the value of Zuidema and Sherbondy's work, to understand finally how water was distributed and used in imperial Cusco, and to see how the ceque system worked, in a practical as well as a ritual sense.
24. In order to reinstitute this kind of equitable system in places where it has been lost, it is not necessary to rebuild all the terraces that have been destroyed and adopt the waterpooling technique. All that is needed is to establish control by the hour, to set time standards for water use per unit of land area and authorize water distributors to enforce them. Incredibly, neither of these now exist in most places where the State has been in control. The methods for accomplishing this are clearly specified in other publications (see Trawick 1994b: chaps. 7-8, 1995, also 1998, in press).

\section{References Cited}

Bolin, Inge

1990 Upsetting the Power Balance: Cooperation, Competition and Conflict along an Andean Irrigation System. Human Organization 49(2): 140-148.

1994 Levels of Autonomy in the Organization of Irrigation in the Highlands of Peru. In Irrigation at High Altitudes: the Social Organization of Water Control Systems in the Andes. Society for Latin American Anthropology Publication Series, 12. William Mitchell and David Guillet, eds. Pp. 233-274. Washington, DC: American Anthropological Association.

Biersack, Aletta

1999 Introduction: From the "New Ecology" to the New Ecologies. American Anthropologist 101(1):5-18.

Cobo, Bernabe

[1653]1964 Obras del P. Bernabe Cobo, vol. 2. Historia del Mundo Andino. Madrid: Biblioteca de Autores Espanoles.

Cook, Noble David

1981 Demografic Collapse: Indian Peru 1520-1620. New York: Cambridge University Press.

Coward, E. Walter

-1979 Principles of Social Organization in an Indigenous Irrigation System. Human Organization 38(1):28-36.

D'Altroy, Terence N.

1987 Introduction. Ethnohistory 34(1):2-23.

Denevan, William, ed.

1986 The Cultural Ecology, Archaeology, and History of Terracing and Terrace Abandonment in the Colca Valley of Southern Peru. Technical Report to the National Science Foundation and the National Geographic Society. Madison: Department of Geography, University of Wisconsin, Madison.

Duviols, Pierre

1973 Huari y Llacuaz, Agricultores y Pastores: Un Dualismo Pre-hispanico de Oposicion y Complementaridad. Revistadel Museo Nacional 39:153-93.

Erasmus, Charles

1965 The Occurrence and Disappearance of Reciprocal Farm Labor in Latin America. In Contemporary Cultures and Societies of Latin America. Dwight B. Heath and Richard N. Adams, eds. Pp. 173-199. New York: Random House.

Ernst, Thomas

-1999 Land, Stories and Resources: Discourse and Entification in Onabasulu Modemity. American Anthropologist 101(1): 88-97.

Escobar, Arturo

1995 Encountering Development: The Making and Unmaking of the Third World. Princeton, NJ: Princeton University Press. 
Flores-Galindo, Alberto

1977 Arequipa y el Sur Andino: Siglo XVIII. Lima: Editorial Horizonte.

Fonseca, Cesar

1983 El Control Comunal del Agua en la Cuenca del Río

Cañete. Allpanchis, An̄o 8, 19(22):61-74.

Fuenzalida, Fernando, T. Valiente, J.L. Villaran, J. Golte, C.I.

Degregori, and J. Casaverde

1982 El Desafio de Huayopampa: Comuneros y Empresarios.

Lima: Instituto de Estudios Peruanos.

Garcilaso de la Vega, Inca

[1609]1966 Comentarios Reales de los Incas, vols. 1-2. H. V.

Livermore, ed. Austin: University of Texas Press.

Gelles, Paul

1986 Sociedades Hidraulicas en los Andes: Algunas Perspectivas desde Huarochiri. Allpanchis, Año 18, (27):99-148.

1994 Channels of Power, Fields of Contention: The Politics of Irrigation and Land Recovery in an Andean Peasant Community. In Irrigation at High Altitudes: The Social Organization of Water Control Systems in the Andes. Society for Latin American Anthropology Publication Series, 12. William P. Mitchell and David Guillet, eds. Pp. 233-274. Washington, DC: American Anthropological Association.

-1995 Equilibrium and Extraction: Dual Organization in the Andes. American Ethnologist 22(4):710-742.

Glick, Thomas

1970 Irrigation and Society in Medieval Valencia. Cambridge, MA: Harvard University Press.

Gootenberg, Paul

1991 Population and Ethnicity in Early Republican Peru: Some Revisions. Latin American Research Review 26(3): 109-157.

Grieshaber, Erwin

1979 Hacienda-Indian Community Relations and Indian Acculturation: An Historiographic Essay. Latin American Research Review 14(3): 107-128.

Guaman Poma de Ayala, Felipe

[1613]1978 Letter to a King: A Peruvian Chief's Account of Life under the Incas and under Spanish Rule. Christopher W. Dilke, trans. New York: Dutton.

Guillet, David

1981 Land Tenure, Ecological Zone and Agricultural Regime in the Central Andes. American Ethnologist 8(1):139-156.

1992 Covering Ground: Communal Water Management and the State in the Peruvian Highlands. Ann Arbor: University of Michigan Press.

1994 Canal Irrigation and the State: The 1969 Water Law and Irrigation Systems in the Colca Valley of Southern Peru. In Irrigation at High Altitudes: The Social Organization of Water Control Systems in the Andes. Society for Latin American Anthropology Publication Series, 12. William P. Mitchell and David Guillet, eds. Pp. 167-188. Washington, DC: American Anthropological Association.

Guillet, David, and William Mitchell

1994 Introduction: High Altitude Irrigation. In Irrigation at High Altitude: The Social Organization of Water Control Systems in the Andes. Society for Latin American Anthropology Publication Series, 12. William P. Mitchell and David
Guillet, eds. Pp. 1-20. Washington, DC: American Anthropological Association.

Hardin, G.

1968 The Tragedy of the Commons. Science 162:1243-1248.

Hendriks, Jan

1986 Distribución de Aguas en Sistemas de Riego. Allpanchis, Año 18,2(28): 185-210.

Hunt, Robert C.

-1988 Size and Structure of Authority in Canal Irrigation Systems. Journal of Anthropological Research 44(4):335-355.

1992 Inequality and Equity in Irrigation Communities. Paper presented at the Third Common Property Conference of the International Association for the Study of Common Property, Washington, DC, September 17-20.

Hunt, Robert C., and Eva Hunt

1976 Canal Irrigation and Local Social Organization. Current Anthropology 17:398-411.

Kearney, Michael

1996 Reconceptualizing the Peasantry. Boulder, CO: Westview Press.

Kelly, William

-1983 Concepts in the Anthropological Study of Irrigation. American Anthropologist 85:880-886.

Kottak, Conrad

-1999 The New Ecological Anthropology. American Anthropologist 101(1):23-35.

Lansing, J. Stephen

1991 Priests and Programmers: Technologies of Power in the Engineered Landscape of Bali. Princeton, NJ: Princeton University Press.

Leach, Edmund

1954 Political Systems of Highland Burma: A Study of Kachin Social Structure. London: Athlone Press.

Levine, Terry $Y$.

1987 Inka Labor Service at the Regional Level: The Functional Reality. Ethnohistory 34(1):15-46.

Mallon, Florence

1983 The Defense of Community in Peru's Central Highlands. Princeton, NJ: Princeton University Press.

Mayer, Enrique

1974 Las Reglas del Juego en la Reciprocidad Andina. In Reciprocidad e Intercambio en los Andes Peruanos. G. Alberti and E. Mayer, eds. Pp. 37-65. Lima: Instituto de Estudios Peruanos.

1977 Beyond the Nuclear Family. In Andean Kinship and Marriage. Special Publication, 7. R. Bolton and E. Mayer eds. Pp. 60-80. Washington DC: American Anthropological Association.

1985 Production Zones. In Andean Ecology and Civilization. S. Masuda, I. Shimada, and C. Morris, eds. Pp. 45-84. Tokio: University of Tokio Press.

Mayer, Enrique, and Cesar Fonseca

1979 Sistemas Agrarios en la Cuenca del Río Cañete. Lima: Oficina Nacional para Evaluación de Recursos Naturales.

Mayer, Enrique, and Cesar Zamalloa

1974 Reciprocidaden las Relaciones de Produccion. In Reciprocidad e Intercambio en los Andes Peruanos. Giorgio Alberti and Enrique Mayer, eds. Pp. 66-86. Lima: Instituto de Estudios Peruanos. 
Mitchell, William P.

-1976 Irrigation and Community in the Central Peruvian Highlands. American Anthropologist 78(1):25-44.

1980 Local Ecology and the State: Implications of Contemporary Quechua Land Use for the Inca Sequence of Agricultural Work. In Beyond the Myths of Culture: Essays in Cultural Materialism. Eric B. Roths, ed. Pp. 139-154. New York: Academic Press.

1994 Dam the Water: The Ecology and Political Economy of Irrigation in the Ayacucho Valley, Peru. In Irrigation at High Altitudes: The Social Organization of Water Control Systems in the Andes. Society for Latin American Anthropology Publication Series, 12. William P. Mitchell and David Guillet, eds. Pp. 275-302. Washington DC: American Anthropological Association.

Mitchell, William P., and David Guillet, eds.

1994 Irrigation at High Altitudes: The Social Organization of Water Control Systems in the Andes. Society for Latin American Anthropology Publication Series, 12. Washington DC: American Anthropological Association.

Montoya, Rodrigo

1980 Capitalismo y No-Capitalismo en el Peru: Un Estudiode su Articulacion en un Eje Regional. Lima: Mosca Azul Editores.

Montoya, Rodrigo, Maria Silveira, and Felipe Rindoso

1979 Produccion Parcelaria y Universo Ideologico: El Caso de Puquio. Lima: Mosca Azul Editores.

Murra, John V.

1960 Rite and Crop in the Inca State. In Culture in History: Essays in Honor of Paul Radin. Stanley Diamond, ed. Pp. 393-407. New York: Columbia University Press.

1975 Formaciones Economicas y Politicas del Mundo Andino: Lima: Instituto de Estudios Peruanos.

1980 The Economic Organization of the Inca State. Greenwich, CT: JAI Press.

Murra, John V., and Nathan Wachtel

1986 Introduction. In Anthropological History of Andean Polities. John Murra, Nathan Wachtel, and Jacques Revel, eds. Pp. 1-8. New York: Cambridge University Press.

Netherly, Patricia

1984 The Management of Late Andean Irrigation Systems on the North Coast of Peru. American Antiquity 49(2):227-254.

Orlove, Benjamin, and Ricardo Godoy

1986 Sectoral Fallowing Systems in the Central Andes. Journal of Ethnobiology 6(1):269-304.

Ostrom, Elinor

1990 Governing the Commons: The Evolution of Institutions for Collective Action. New York: Cambridge University Press.

Paerregaard, Karsten

1994 Why Fight over Water? Power, Conflict and Irrigation in an Andean Village. In Irrigation at High Altitudes: The Social Organization of Water Control Systems in the Andes. William P. Mitchell and David Guillet, eds. Pp. 189-202. Society for Latin American Anthropology Publication Series, 12. Washington, DC: American Anthropological Association.

Painter, Michael

1992 Re-Creating Peasant Economy in Southern Peru. In Golden Ages, Dark Ages: Imagining the Past in Anthropol- ogy and History, Jay O'Brien and William Roseberry, eds. Pp. 302-345. Berkeley: University of California Press.

Rappaport, Roy A.

1968 Pigs for the Ancestors. New Haven, CT: Yale University Press.

1979 Ecology, Meaning and Religion. Richmond, CA: North Atlantic Books.

-1993 The Anthropology of Trouble. American Anthropologist 95:295-303.

Schaedel, Richard P.

1971 Commonality in Processual Trends in the Urbanization Process: Urbanization and the Redistributive Function in the Central Andes. Discussion Paper, Center for Latin America, University of Wisconsin at Milwaukee.

Schlager, Edella, and Elinor Ostrom

1992 Property-Rights Regimes and Natural Resources: A Conceptual Analysis. Land Economics 68(3):249-262.

Scott, James C.

1976 The Moral Economy of the Peasant: Rebellion and Subsistence in Southeast Asia. New Haven, CT: Yale University Press.

1985 Weapons of the Weak: Everyday Forms of Peasant Resistance. New Haven, CT: Yale University Press.

Seligmann, Linda J., and Stephen G. Bunker

1994 An Andean Irrigation System: Ecological Visions and Social Organization. In Irrigation at High Altitudes: The Social Organization of Water Control Systems in the Andes. Society for Latin American Anthropology Publication Series, 12. William P. Mitchell and David Guillet, eds. Pp. 203-232. Washington, DC: American Anthropological Association.

Sherbondy, Jeannette E.

1986 Los Ceques: Código de Canales en el Cusco Incaíco.Allpanchis, Año 18, (27):39-74.

1994 Water and Power: The Role of Irrigation Districts in the Transition from Inca to Spanish Cuzco. In Irrigation at High Altitudes: The Social Organization of Water Control Systems in the Andes. Society for Latin American Anthropology Publication Series, 12. William P. Mitchell and David Guillet, eds. Pp.69-98. Washington, DC: American Anthropological Association.

Smith, Gavin

1989 Livelihood and Resistance. Berkeley: University of California Press.

Starn, Orin

1991 Missing the Revolution: Anthropologists and the War in Peru. Cultural Anthropology 6:63-91.

Steward, Julian H., ed.

1949 Cultural Causality and Law: A Trial Formulation of the Development of Early Civilizations. American Anthropologist 51:1-27.

1955 Irrigation Systems: A Comparative Study. Pan American Union Social Science Monographs, 1. Julian Steward, ed. Washington, DC.

Thompson, I. G., M. E. Mosely, J. F. Bolzan, and B. R. Koci

1985 A 1,500 Year Record of Tropical Precipitation from the Quelccaya Ice Cap. Science 229:971-973.

Trawick, Paul B.

1994a The Struggle for Water in the Andes: A Study of Technological Change and Social Decline in the Cotahuasi Valley of Peru. Ph.D.Dissertation, Yale University. 
1994b Historia de la Irrigación y Conflictos de Classes en la Sierra. Debate Agrario 18:21-44. Lima: Centro Peruano de Estudios Sociales.

1995 Water Reform and Poverty in the Peruvian Highlands. In Peru: A User-Based Approach to Water Management and Irrigation Development. Mateen Thobani, ed. Annex B, World Bank Report, 13642-Pe. Washington, DC: World Bank.

1998 La Nueva Ley de Aguas: Alternativa Indigena a las Reformas Propuestas. Debate Agrario, 28. Lima: Centro Peruano de Estudios Sociales.

- 2001 Successfully Governing the Commons: Principles of Social Organization in an Andean Irrigation System. Human Ecology 29(1):1-25.

In press The Struggle for Water in Peru: Comedy and Tragedy in the Andean Commons. Palo Alto, CA: Stanford University Press.

Treacy, John

1994a Las Chacras de Corporaque: Andeneria y Riego en el Valle del Colca. Lima: Instituto de Estudios Peruanos.

1994b Teaching Water: Hydraulic Management and Terracing in Corporaque, the Colca Valley, Peru. In Irrigation at High Altitudes: The Social Organization of Water Control Systems in the Andes. Society for Latin American Anthropology
Publication Series, 12. William Mitchell and David Guillet, eds. Pp. 99-114. Washington, DC: American Anthropological Association.

Trouillot, Michel-Rolph

1988 Peasants and Capital: Dominica in the World Economy. Baltimore: Johns Hopkins University Press.

Valderamma, Ricardo, and Carmen Escalante

1988 Del Tata Mallku a la Mama Pacha: Riego, Sociedad y Ritos en los Andes Peruanos. Lima: Centro de Estudios y Promocion del Desarollo.

Wittfogel, Karl A.

1955 Developmental Aspects of Hydraulic Civilization. In Irrigation Systems: A Comparative Study. Pan American Union Social Science Monographs, 1. Julian Steward, ed. Washington, DC .

1957 Oriental Despotism: A Comparative Study of Total Power. New Haven, CT: Yale University Press.

Zuidema, Tom R.

1964 The Ceque System of Cusco. Leiden: E. J. Brill.

1986 Inka Dynasty and Irrigation: Another Look at Andean Concepts of History. In Anthropological History of Andean Polities. John Murra, Nathan Wachtel, and Jacques Revel, eds. Pp. 177-200. New York: Cambridge University Press. 